\title{
Pengaruh token ekonomi untuk meningkatkan kemampuan rawat diri pada individu dengan gangguan skizoafektif
}

$\Phi$ PROCEDIA Studi Kasus dan Intervensi Psikologi p-ISSN 2302-1462; e-ISSN 2722-7669 ejournal.umm.ac.id/index.php/procedia 2021, Vol 9(4):145-151

DOI:10.22219/procedia.v9i4.16346

(c) The Author(s) 2021

(1)(3) 4.0 International license

\author{
Rullita Aristya Mintarsih ${ }^{1}$
}

\begin{abstract}
The subject was a 41-year-old woman with a diagnosis of schizoaffective disorder. Subjects showed the symptoms of schizoid that made them less interested in daily activities, less concerned with hygiene and self-care. Assessment methods used are observations, interviews, and psychological tests in the form of WAIS, graphic tests DAP, BAUM, \& HTP, TAT, WWQ and WHODAS questionnaire. Interventions are made to deal with the lack of ability in selfcare, using behavior modification therapy with the token economy method. The results showed that Token Economy was effective to improve the subject's ability to care for themselves, they became more motivated to perform basic activities such as self-cleaning.
\end{abstract}

\section{Keywords}

Schizoaffective disorder, behavior modification, self-care, economic tokens

\section{Pendahuluan}

Gangguan skizoafektif merupakan gejala gangguan mental berupa gejala psikotik dan gejala afektif (Bai et al., 2018). Untuk menegakkan diagnosa pada gangguan ini setidaknya individu telah menunjukkan gejala psikotik berupa gejala positif dua minggu dan disertai dengan gejala gangguan mood seperti manik dan depresif. Selama selang waktu individu memiliki gejala psikotik, apabila individu menunjukkan adanya kehilangan ketertarikan terhadap sesuatu yang menyenangkan yang merupakan salah satu gejala gangguan mood serta memenuhi kriteria yang ada pada gangguan maka, individu tersebut dapat dikatakan menderita skizoafektif (American Psychological Association, 2013).

Gejala klinis yang paling utama adalah kesalahan persepsi yang memunculkan halusinasi dan delusi, cara berpikir yang terganggu dan tidak terorganisir, permasalahan pada afeksi, serta gangguan pada gerak motor dan perilakunya. Namun secara khusus, gangguan skizoafektif. Selain memiliki gejala yang ada dalam gangguan skizofrenia, gangguan ini juga memiliki gejala gangguan mood depresi dan mania. Penderita yang mengalami gangguan mental yang parah sering menunjukkan adanya ketidakmampuan secara sosial dan ketidakberfungsian dalam kehidupan sehari-hari sehingga dapat berdampak pada perilaku isolasi sosial.

Pasien dengan gejala diatas berpengaruh pada bagaimana mereka berfungsi dalam kehidupan seharihari. Gejala-gejala psikotik pada penderita skizoafektif dapat diberikan treatment berupa farmakologi untuk menstabilkan emosi dan antidepresan (Joshi et al.,
2016). Obat jenis ini dapat mengurangi terjadinya relapse. Namun, keberfungsian hidup sehari-hari juga menjadi bagian penting yang perlu dikembangkan dan ditingkatkan. Hal ini terjadi karena umumnya penderita gangguan mental memiliki kekurangan pada fungsi berkomunitas, hubungan interpersonal, strategi pemecahan masalah, dan keterampilan baru (Rus-Calafell et al., 2014). Dengan meningkatkan keberfungsian penderita dalam kehidupan sehari-hari yang dilakukan secara teratur dan terstruktur, mereka dapat membiasakan diri dengan keterampilan-keterampilan sosial serta perawatan diri.

Inidvidu yang menderita gangguan skizoafektif secara umum kurang memperhatikan kebersihan diri. Mereka kurang memperhatikan kondisi rambut, kuku, tubuh, mulut, dan cara berpakaian. Sebagaimana hasil penelitian menunjukkan bahwa terdapat hubungan negative antara persepsi diri tentang kebersihan dengan hasil asesmen dari perawat (Hsu, 2017). Hal ini menunjukkan bahwa ketika pasien beranggapan bahwa dirinya telah menjaga kebersihan diri atau melakukan perawatan pada diri tidak berarti bahwa hasil asesmen kebersihan diri mereka juga dinilai baik oleh perawatnya.

Subjek merupakan penderita gangguan skizoafektif yang telah dirawat di Yayasan sejak tahun 2013 hingga sekarang. Subjek sebelumnya telah menderita gangguan emosi

\footnotetext{
${ }^{1}$ Universitas Muhammadiyah Malang,Indonesia
}

Korespondensi:

Rullita Aristya Mintarsih, Direktorat Program Pascasarjana, Universitas Muhammadiyah Malang, Jl. Tlogomas 246 Malang, Indonesia Email: aisyahputrirawe@gmail.com 
karena masalah percintaan yang tidak direstui oleh orang tuanya. Subjek sering menyendiri, menangis serta marahmarah di dalam kamar. Ia memaki-maki orang di depannya atau di tembok karena beranggapan bahwa ada yang mengolok-olok dirinya.

Permasalahan tersebut membuat subjek tidak tertarik melakukan aktivitas sehari-hari. Ia lebih senang jika hanya duduk-duduk atau tidur di kamar. Ketika emosi subjek sedang tidak baik tanpa sebab yang jelas, ia akan lebih banyak termenung dan kurang tertarik dengan aktivitas sosial. Perubahan emosi ini menyebabkan subjek mudah merasa malas untuk melakukan aktivitas sehari-hari, jadi ia juga kurang memperhatikan perawatan diri dan kebersihan rambut, kuku, tubuh, mulut serta pakaiannya sehingga penampilannya terkesan lusuh. Subjek beranggapan bahwa ia telah membersihkan diri seperti mencuci rambutnya tanpa menggunakan sampoo. Akibatnya, rambut subjek ditumbuhi kutu, gatal dan tidak terawat.

\section{Metode Asesmen}

Asasmen dilakukan dengan metode observasi, wawancara, dan tes psikologi. Observasi dilakukan pada saat kegiatan sehari-hari Subjek, wawancara, dan pada saat tes berlangsung. Tujuan metode observasi ini adalah untuk mengamati pola perilaku Subjek pada saat berada pada suatu situasi (tes psikologi dan wawancara), serta bagaimana perilaku Subjek dalam kehidupan sehari-harinya. Wawancara dilakukan dengan Subjek (autoanamnesa), dan penjaga Yayasan tempat Subjek dirawat (alloanamnesa).

Tujuannya adalah untuk mengumpulkan data-data yang berhubungan dengan Subjek yang berguna untuk melakukan penegakkan diagnosa. Tes psikologi yang diberikan berupa tes intelegensi WAIS yang bertujuan untuk mengetahui tingkat kecerdasan berdasarkan kemampuan verbal dan performance, serta apakah terdapat kemunduran mental atau kerusakan otak. Tes grafis yang terdiri dari tes DAP, BAUM, dan HTP. Tes DAP dan BAUM dimaksudkan untuk memahami struktur kepribadian dan kecenderungan dalam berhubungan dengan lingkungan sosialnya. Sedangkan tes HTP digunakan untuk mengetahui hubungan dan persepsi subjek terhadap peran ayah dan ibu serta bagaimana hubungan interpersonalnya. Tes TAT diberikan untuk mengetahui konflik-konflik yang dimiliki sehingga ia dapat memproyeksikan konflik terpendam pada ceritanya. Untuk menguatkan penegakan diagnosa, Subjek diberikan WWQ agar dapat diketahui kecenderungan patologis. Kuesioner WHODAS juga diberikan untuk mengetahui seberapa besar keberfungsian dalam kehidupannya sehari-hari.

\section{Presentasi Kasus}

Subjek seorang wanita paru baya berusia 41 tahun, memiliki badan gemuk dengan penampilan sederhana. Subjek merupakan anak terakhir dari lima bersaudara. Namun, subjek memiliki dua adik dari ibu sambungnya.
Ayahnya adalah figur ayah yang dominan dan tegas, sedangkan ibu kandungnya telah lama meninggal. Sejak kecil, subjek telah di rawat oleh ibu sambungnya karena kakak-kakaknya tinggal di luar kota untuk bekerja. Ibu sambungnya adalah wanita yang ramah, baik, dan nyaman dalam berkomunikasi. Subjek pertama kali datang ke Yayasan rehabilitasi psikologi diantarkan oleh kakaknya dengan keluhan pusing di kepala dan suka marah-marah. Subjek telah tinggal di Yayasan kurang lebih dari 6 tahun. Sebelumnya pernah di rawat di RSJ selama dua bulan.

Berdasarkan hasil asesmen tersebut, permasalahan yang dialami dapat dijelaskan dengan model diatesis stress dimana terdapat pengaruhnya dari faktor biologis, psikososial dan lingkungan. Model ini dapat mengungkapkan bahwa gejala skizofrenia yang dialami individu dapat disebabkan oleh kerentanan spesifik (diatesis), yang apabila terdapat situasi lingkungan yang menimbulkan stress maka memungkinkan munculnya gejala skizofrenia pada penderita. Subjek terlahir normal dan berkembang sebagaimana anak seusianya. Meskipun ia memiliki hambatan dalam memahami pelajaran selama masa pendidikannya. Berdasarkan hasil tes, Subjek memiliki IQ mental defective dimana ia kesulitan untuk memahami sesuatu tanpa bantuan orang lain. Selain itu, subjek tidak memiliki riwayat keluarga yang memiliki gangguan mental. Hal ini menunjukkan bahwa ia memiliki kerentanan biologis dari segi intelegensinya.

Permasalahan Subjek dapat dilihat dari kerentanan psikologis dimana Subjek memiliki kepribadian yang berkemauan keras. Namun cenderung tertutup, pendiam dan penyendiri. Ia juga memiliki hambatan dalam mengelola emosinya. Subjek memiliki emosi yang datar (emotion flatness) dimana ia kurang mampu mengungkapkan perasaan yang sebenarnya kepada orang lain, mudah merasa ragu-ragu, cemas dan takut apabila mendapatkan penolakan dari orang lain atau kurangnya dukungan dari keluarga, juga kurang memiliki ketertarikan dalam berinteraksi sosial dan memiliki kesulitan dalam mengungkapkan perasaannya pada orang lain. Hal ini menyebabkan subjek lebih sering melamun dan cenderung merasa depresif jika terjadi suatu masalah dan ketika harapannya tidak terpenuhi.

Subjek memiliki sosok ayah yang tegas dan disiplin terhadap anak-anaknya dalam hal pendidikan. Berdasarkan penuturan kakaknya, ayah cenderung menggunakan kekerasan apabila anak-anaknya tidak belajar sesuai waktunya. Ayah juga tidak segan untuk menggunakan cambuk. Namun, Subjek memiliki kesulitan untuk mengikuti kemauan ayahnya dengan tingkat kecerdasan yang dimilikinya. Hal ini membuat frustrasi dengan perlakuan ayahnya sehingga sering menggunakan reaksi formasi untuk menggambarkan sosok ayahnya yaitu sebagai ayah yang baik dan bertanggung jawab.

Subjek tidak mampu menentang otoritas ayahnya jadi ia merasa harus menjadi anak yang penurut dan menuruti semua permintaan ayah kepadanya. Oleh karena itu, permasalahan muncul (onset) adalah saat SMA dimana ia 
meminta ijin kepada orang tuanya untuk berpacaran namun tidak diijinkan oleh ayah dan ibunya karena perlu berfokus pada sekolahnya. Setelah penolakan dari keluarga, ia lebih sering menyendiri di kamar dan sering berbicara sendiri. Terkadang berteriak-teriak karena merasa ada yang mengajaknya bicara dan mendengar suara-suara, namun tidak ada yang bisa melihat sosok yang mengajak bicara kecuali ia sendiri.

Selain gejala halusinasi audio dan visual tersebut, Subjek juga menunjukkan penurunan aktivitas dimana ia selalu merasa malas untuk beraktivitas sehingga pekerjaan yang dilakukannya tidak pernah selesai. Rekan kerja mengeluhkan bahwa ia tidak pernah menyelesaikan pekerjaannya dan menyusahkan orang-orang disekitarnya. Subjek juga akan marah apabila diingatkan untuk melakukan suatu pekerjaan tertentu seperti mandi, mencuci baju, atau menyapu. Gejala lain adalah subjek tidak tertarik berinteraksi sosial sebab ia lebih sering menyendiri dengan dunianya. Ia berbicara sendiri sambil menangis atau marah-marah sampai merusak barang.

Pola pengasuhan dari ayah Subjek yang otoriter membuat Subjek kurang mendapatkan dukungan secara emosional. Ayah Subjek kurang mampu memahami kekurangan Subjek sehingga ia sering memaksa Subjek untuk lebih mengutamakan pendidikan daripada perasaan dan percintaannya. Pola pengasuhan ini menjadi anteseden (A) dari munculnya perilaku pada Subjek. Perilaku (B) yang muncul adalah Subjek lebih sering menyendiri, menangis, dan berbicara sendiri saat keinginannya tidak dapat terpenuhi. Subjek juga meluapkan emosi marahnya apabila disuruh atau dipaksa melakukan sesuatu oleh orang lain. Dampaknya (C) adalah Subjek tidak mampu mengelola emosinya jika ia dalam kondisi sangat tertekan serta tidak tertarik melakukan kegiatan sehari-hari.

Gejala-gejala yang muncul pada Subjek menunjukkan bahwa Subjek mengalami gangguan skizofrenia dengan perubahan emosi yang cepat dari emosi manik (marahmarah) ke depresi (menangis dan tidak tertarik dengan aktivitas sehari-hari). Akan tetapi, gejala-gejala ini telah mengalami penurunan setelah diberikan penanganan medis berupa obat psikotik. Selama observasi, Subjek tidak menunjukkan tanda-tanda marah yang tidak bisa dikontrol meskipun terkadang Subjek menunjukkan emosi marahnya pada objek tertentu dengan menggunakan kata-kata kasar. Umumnya, Subjek marah jika ia merasa tidak diperlakukan secara adil atau merasa dirinya sedang dibicarakan orang lain.

Berdasarkan observasi juga menunjukkan bahwa gejala depresif Subjek masih tampak. Misalnya, Subjek lebih suka menyendiri, emosinya yang datar hampir setiap hari muncul, berkurangnya ketertarikan untuk melakukan suatu kegiatan, peningkatan berat badan, sulit tidur atau kebanyakan tidur, dan sering melamun sambil memperhatikan jalan raya tanpa ekspresi. Subjek juga terkadang menunjukkan rasa sedihnya karena tidak mendapatkan kunjungan dari keluarga dan selalu mengatakan bahwa ia rindu dengan keluarganya. Ia sering menangis di kamar saat teringat dengan keluarganya di rumah.

Namun, masalah yang menjadi perhatian utama bagi Subjek adalah kurangnya kemampuan Subjek dalam melakukan perawatan diri dimana ia jarang merawat kondisi rambutnya. Ia jarang menyisir rambutnya sendiri atau mencuci rambut dengan sampo sehingga rambutnya berkutu. Subjek juga tidak menyikat gigi dengan benar sehingga giginya menguning. Ia juga kurang memperhatikan penampilannya karena jarang mengganti baju. Subjek mengganti baju sekali dalam tiga hari akibatnya tidak jarang Subjek menimbulkan bau yang tidak sedap. Hal ini dapat mengganggu penghuni lain serta petugas yang bekerja di Yayasan.

Subjek telah terbiasa merawat diri dengan mandi atau menyikat gigi seperlunya saja. Subjek tidak dapat menilai apakah perawatan diri yang dilakukannya sudah benar atau belum. Tidak adanya kontrol dari lingkungan karena petugas sibuk dengan pasien lain dan tidak adanya yang mengajarkan kepada Subjek tentang perawatan diri yang baik dan benar menyebabkan Subjek merasa telah melakukan sesuatu dengan benar. Sehingga perilaku ini terus berulang.

Perilaku bermasalah perawatan diri ini biasa dialami oleh pasien skizofrenia. Mereka yang mengalami gangguan ini cenderung mengalami defisit perawatan diri karena hilangnya kebutuhan untuk mendapatkan rasa nyaman dari kebersihan diri (Sasmita, 2012). Mereka cenderung tidak menghiraukan penampilan dan kebersihan diri. Akibatnya, individu dapat mengalami gangguan fisik seperti penyakit kulit seperti gatal, gigi tidak terawat dan keropos, kuku yang panjang dan kotor, serta bau yang kurang sedap. Untuk itu, keterampilan Subjek dalam merawat diri perlu ditingkatkan dengan memodifikasi perilaku Subjek menggunakan metode token ekonomi.

Terapis menggunakan metode intervensi dengan token ekonomi. Selain pemberian token, reinforcement positive tidak selalu berupa hadiah (tangible reinforcers) yang disenangi oleh Subjek karena dalam pemberian rewards sangat perlu memperhatikan dampaknya agar tidak menimbulkan ketergantungan pada Subjek.

\section{Diagnosis dan Prognosis}

Diagnosis bagi subjek adalah gangguan Skizoafektif (295.70/F25.0) ditandai dengan perubahan emosi (manik, depresif) secara bersamaan selama masa gangguan. Hal ini berdampak pada kurangnya minat Subjek dalam beraktivitas dan melakukan pekerjaan hanya seperlunya saja. Sehingga memunculkan permasalahan kurangnya kemampuan dalam perawatan diri dan menjaga kebersihan. Hasil WHODAS menunjukkan skor 3,9 yang berarti bahwa Subjek memiliki keterbatasan untuk melakukan aktivitas tertentu namun Subjek masih cukup mampu mengerjakan kegiatan sehari-hari.

Prognosis positif karena Subjek masih memiliki kemauan dalam melakukan aktivitas tertentu jika disuruh. 
Ia juga cukup memahami perlunya memperhatikan penampilan diri dengan merawat dirinya. Serta adanya dukungan dari keluarga untuk kesembuhan Subjek dari permasalahannya.

\section{Intervensi}

Metode intervensi yang digunakan adalah token ekonomi. Token ekonomi merupakan metode yang efektif dalam mengubah perilaku Subjek dengan memberikan imbalan atas perilaku yang dikehendaki apabila Subjek dapat melakukannya (Sunarsih \& Holidy, 2017). Kegiatan ini dilakukan agar Subjek dapat melakukan perawatan diri secara rutin. Sehingga ia dapat terbiasa menjaga dan merawat kebersihan diri meskipun ia sedang dmengalami perubahan emosi dan merasa malas untuk beraktivitas. Subjek akan diberikan token yang dapat ditukarkan dengan hadiah sebagai bentuk penguatan atas perilakunya. Berikut adalah tahapan pelaksanaan metode token ekonomi:

Sesi I: Identifikasi Masalah. Terapis menjelaskan pentingnya melakukan perawatan diri dalam kehidupan seharihari.kepada Subjek Penjelasan ini dilakukan bertujuan untuk memberikan pemahaman kepada Subjek tentang perawatan diri yang selama ini dilakukan masih perlu ditingkatkan agar Subjek dapat terus menjaga kebersihan tubuhnya.

Sesi ini dilakukan pada hari pertama pertemuan. Terapis memberikan penjelasan kepada Subjek tentang permasalahan yang dimilikinya yaitu kurangnya kemampuan Subjek dalam merawat diri. Subjek sepakat dengan terapis bahwa ia perlu meningkatkan kebersihan dirinya agar ia mampu merawat diri dalam kehidupan sehari-hari secara mandiri. Pada sesi ini, Subjek menyatakan kesediaannya untuk melakukan target-target perilaku dalam meningkatkan kemampuan perawatan dirinya.

Sesi II: Pengenalan Intervensi dan Menentukan Target Perilaku yang diharapkan. Terapis mengenalkan token ekonomi beserta target perilaku yang akan dilakukan. Tahap (1) Target perilaku yang diharapkan adalah Subjek mampu melakukan perawatan diri yaitu berupa mandi dengan sabun, keramas dengan sampo, menggosok gigi, menyisir rambut, berdandan/merapikan penampilan, mengganti pakaian, dan membersihkan kuku. Tahap (2) Mengidentifikasi item yang dapat menjadi token. Token yang diberikan adalah tanda yang bergambar bunga terbuat dari kertas karena Subjek menyukai gambar bunga. Bentuk ini akan menarik perhatian Subjek sehingga ia termotivasi untuk melakukan kegiatan perawatan diri. Tahap (3) Mengidentifikasi back up reinforce.

Penguatan yang diberikan adalah berupa hadiah makanan ringan yang disenangi oleh Subjek. Serta makanan dengan lauk ayam dan es jeruk. Tahap (4) Menentukan jadwal pemberian reinforcer. Penguatan berupa hadiah diberikan apabila Subjek telah mengumpulkan token yaitu di akhir sesi. Tahap (5) Menetapkan banyaknya token yang bisa ditukar. Subjek dapat menukar token dengan hadiah yang diinginkannya jika ia mampu mengumpulkan sebanyak token yang telah ditentukan yaitu sebanyak 25 token. Tahap (6) Menetapkan waktu dan tempat penukaran. Subjek akan memiliki papan token ekonomi, didalamnya terdapat tempat untuk mengumpulkan token. Setelah banyak token dikumpulkan oleh Subjek maka ia akan mendapatkan hadiah yang diinginkannya.

Terapis bersama Subjek menentukan target-target perilaku yang akan dilakukan Subjek. Target perilaku tersebut adalah mandi dan menggsok gigi dua kali sehari, keramas dengan sampoo, menyisir rambut, memotong/membersihkan kuku, dan mengganti pakaian. Terapis menjelaskan kepada Subjek bahwa ia akan mendapatkan token berupa sticker setiap kali ia dapat melakukan target perilakunya. Subjek bisa menukar token tersebut dengan hadiah yang disenanginya berupa snack atau jajanan anakanak sekolah, minuman teh gelas, dan makanan nasi ayam bakar serta es jeruk. Rewards ini akan diberikan setelah Subjek dapat mengumpulkan jumlah token yang telah ditentukan yaitu 15 token untuk snack dan minuman, dan 25 token untuk nasi ayam bakar dan es jeruk.

Sesi III: Implementasi Token Ekonomi Implementasi token ekonomi dalam waktu seminggu dengan kegiatan merawat diri lain pada setiap sesinya. Pelaksanaan ini dilakukan dengan menanyakan Subjek apakah Subjek telah mandi dengan sabun dan menggosok gigi setiap harinya. Terapis juga mendorong Subjek agar mau mengerjakan target perilaku yang dapat dilakukan setiap hari seperti menyisir rambut atau membersihkan kuku. Serta mendorong Subjek agar membuat jadwal untuk keramas dengan sampoo dan mengganti baju.

Token-token yang telah dikumpulkan oleh Subjek dapat ditukarkan dengan makanan yang diinginkan oleh Subjek yaitu lalapan nasi tempong dengan lauk ayam bakar dan minuman es jeruk. Subjek merasa senang ketika mendapatkan token setelah melakukan kegiatan yang menjadi target perilaku dari intervensi. Subjek juga diberikan pujian untuk menyemangatinya agar dapat melakukan perawatan diri secara teratur.

Sesi IV: Monitoring. Monitoring dilakukan setelah pemberian token ekonomi diberikan. Sesi ini bertujuan untuk memantau apakah Subjek tetap melakukan target perilaku yang diharapkan ketika token tidak lagi diberikan. Monitoring dilakukan selama empat hari setelah pemberian token dihentikan dengan menanyakan apakah Subjek telah melakukan target perilaku setiap harinya. Subjek diberikan pujian jika dapat melakukan target perilaku yang diharapkan dan diberikan motivasi agar terus menjaga kebersihan dirinya.

Sebelumnya, Subjek diberikan penjelasan bahwa pemberian token akan dihentikan namun terapis tetap mendorong Subjek agar tetap melakukan perawatan diri meskipun terapis tidak memberikan token. Setiap hari, terapis akan bertanya kepada Subjek apakah ia sudah melakukan target perilaku pada hari tersebut. Jika 
Subjek dapat melakukannya, terapis tidak memberikan token tetapi memberikan pujian agar Subjek termotivasi untuk melakukan kegiatan-kegiatan perawatan diri setiap harinya. Apabila Subjek belum melakukan salah satu target perilaku, terapis memberikan dorongan pada Subjek untuk melakukan target perilakunya dan pemahaman agar Subjek tetap menjaga perawatan diri.

Sesi ini, Subjek menunjukkan adanya perubahan perilaku dimana ia dapat melakukan perawatan diri dan menentukan jadwal. Subjek setiap hari melakukan kegitan perawatan diri tanpa pemberian token yaitu mandi dengan sabun dua kali sehari, menggosok gigi dua kali saat mandi ditambah setelah makan, keramas dengan sampoo setiap dua hari sekali, menyisir rambut, dan membersihkan kuku. Artinya, Subjek telah menunjukkan perubahan perilaku tanpa adanya reinforcement dari luar berupa token.

Sesi V: Evaluasi dan Terminasi Evaluasi dan terminasi bertujuan untuk mengevaluasi ada tidaknya perubahan perilaku yang telah ditunjukkan oleh Subjek dan menentukan perlu tidaknya penerapan implementasi kembali. Apabila Subjek telah menunjukkan adanya perubahan perilaku maka terapis dapat mengakhiri serangkaian sesi.

Disini terapis menganalisa perubahan yang terjadi adalah karena Subjek merasa senang saat mendapatkan hadiah (token) ketika ia dapat melakukan target perilaku. Subjek juga senang ketika ia mendapatkan pujian dari orang lain sehingga hal ini membuatnya terdorong untuk mempertahankan perubahan perilakunya. Subjek juga mendapatkan dukungan dari keluarga berupa persediaan peralatan mandi. Sebelum intervensi, Subjek sering malas menggunakan sampoo karena ia tidak memiliki sampoo dan penjaga Yayasan hanya akan memberikan sampoo sachet saat kondisi rambut Subjek benar-benar kotor. Tetapi, sekarang Subjek memiliki sampoo berbentuk botol pemberian dari kakak Subjek. Ia sering menggunakan sampoo tersebut sesuai jadwal yang telah dibuatnya sendiri yaitu dua hari sekali. Selain itu, Subjek juga menjaga penampilannya dengan selalu terlihat rapi karena Subjek sering menyisir rambutnya setelah bangun tidur dan mandi. Karena Subjek telah menunjukkan perubahan perilaku, terapis memutuskan untuk menghentikan intervensi yang telah dilakukan.

Sesi VI: Follow Up. Follow up merupakan sesi yang bertujuan untuk mengevaluasi apakah perubahan perilaku yang ditunjukkan Subjek dapat dipertahankan selama kurun waktu yang ditentukan yaitu dua bulan setelah pelaksanaan intervensi. Follow up dimaksudkan agar terapis dapat mengetahui perubahan perilaku yang terjadi pada Subjek adalah hasil dari penerapan metode token ekonomi yang telah dilakukan.

Terapis melakukan pertemuan dengan Subjek seminggu setelah pelaksanaan intervensi. Terapis menanyakan kepada Subjek tentang perawatan diri yang dilakukannya, Subjek mengatakan bahwa ia membiasakan diri untuk mandi setiap hari dan keramas setiap dua hari sekali. Selain itu, penjaga Yayasan juga turut mengingatkan

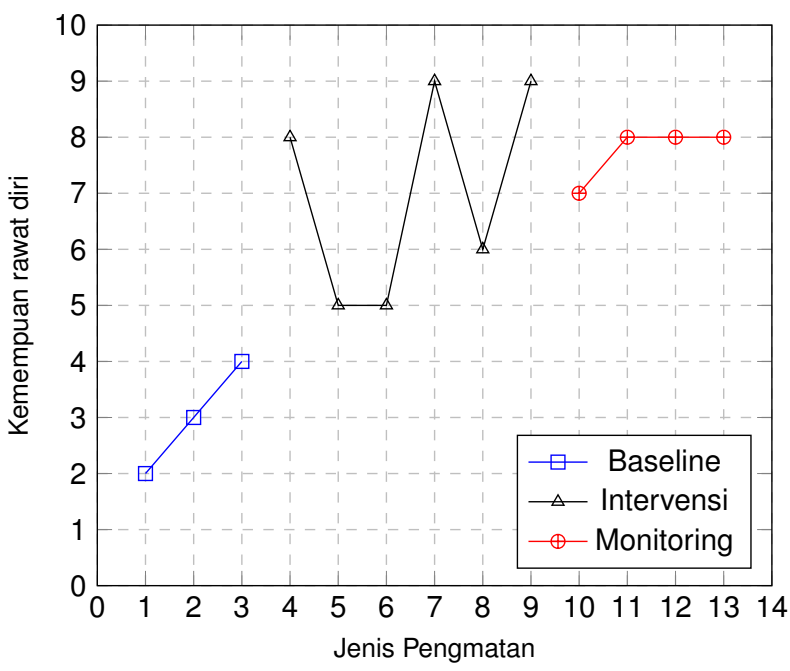

Gambar 1. Hasil intervensi.

Subjek apabila Subjek lupa melakukannya namun penjaga Yayasan mengaku belum pernah mengingatkan karena Subjek dapat melakukan sendiri tanpa diminta. Hal ini menunjukkan bahwa Subjek telah mampu melakukan perawatan diri setiap hari. Perubahan perilaku ini juga nampak pada penampilan Subjek yang terlihat bersih dan rapi. Rambutnya jadi lebih terawat dan tersisir rapi. Pakaian Subjek juga tidak lusuh seperti saat sebelum intervensi.

\section{Hasil dan Pembahasan}

\section{Hasil}

Hasil dari intervensi menunjukkan bahwa Subjek dapat merawat diri dengan mandi dan menggosok gigi secara teratur serta kegiatan perawatan diri lain.

Sebagaimana Gambar 1 hasil intervensi menunjukkan adanya peningkatan dibandingkan dengan saat sebelum intervensi. Subjek secara rutin dapat melakukan kegiatan mandi sebanyak dua kali sehari menggunakan sabun. Ia juga secara rutin menggosok giginya namun saat intervensi berlansung, Subjek justru menunjukkan perilaku baru yaitu menggosok gigi setelah makan. Meskipun sebenarnya perilaku tersebut tidak menjadi target dari intervensi. Subjek menunjukkan peningkatan perilaku dalam melakukan keramas dengan sampoo. Dalam hal ini, Subjek membiasakan diri untuk mencuci rambutnya dengan sampoo sekali dalam dua hari. Hasilnya, rambut Subjek lebih terlihat sehat meskipun masih terdapat telur kutu di bagian bawah rambutnya.

Selain itu, Subjek juga mengalami peningkatan dalam menyisir rambut dan memotong/membersihkan kukunya dari kotoran. Dalam membersihkan kuku, Subjek dapat melakukannya sendiri tetapi tetap dalam pengawasan agar ia tidak melukai tangannya. Terakhir adalah perilaku mengganti pakaian, awalnya Subjek mengenakan baju 
selama tiga hari berturut-turut. Tapi akhirnya Subjek menggunakan pakaian yang sama hanya dalam dua hari.

\section{Pembahasan}

Berdasarkan hasil intervensi, penerapan metode token ekonomi dapat membantu Subjek dalam meningkatkan keterampilannya dalam merawat diri dan menjaga kebersihan. Aktivitas kebersihan diri yang diterapkan kepada Subjek selama 6 hari ini memberikan dampak positif pada Subjek yaitu Subjek dapat merasakan pentingnya kebersihan bagi dirinya. Selaras dengan hasil intervensi ini, Sasmita (2012) juga mengungkapkan dalam penelitiannya bahwa metode token ekonomi efektif digunakan untuk mengajarkan pada pasien yang mengalami defisit perawatan diri.

Gangguan skizoafektif merupakan penyakit yang parah karena memiliki perbedaan dibandingkan dengan penderita gangguan skizofrenia umumnya yaitu adanya gejala afektif yang mengalami perubahan dengan cepat (DeRosse et al., 2013). Gejala afektif ini memiliki perbedaan dengan gejala negatif seperti avolition, alogia, dan anhedonia karena diperlukan pemenuhan kriteria dari gangguan depresif major atau bipolar. Sehingga dapat dikatakan bahwa gangguan skizoafektif telah mewakili gejala-gejala yang ada dalam gangguan skizofrenia dan bipolar. Pasien yang menderita skizoafektif mengalami perubahan emosi yang kadang tidak terduga karena itu ia mudah sekali berubah menjadi tidak tertarik dengan aktivitas seharihari. Pasien dengan gangguan psikotik yang memiliki masalah dalam perawatan diri dapat mempengaruhi kualitas hidupnya (Arsova et al., 2014). Akibatnya Subjek jadi kurang memperhatikan kebersihan diri dan kurang mampu merawat diri dengan baik meskipun ia merasa dirinya telah benar dalam merawat diri (Hsu, 2017).

Penerapan token ekonomi untuk meningkatkan kemampuan perawatan diri bagi pasien psikotik sangat diperlukan, terlebih apabila Subjek merupakan individu yang belum menikah, belum memiliki anak, dan jauh dari keluarga (Tas \& Buldukoglu, 2018). Subjek membutuhkan kemampuan untuk merawat dirinya sendiri sehingga ketika ia telah keluar dari Yayasan ia mampu secara mandiri melakukan aktivitas-aktivitas dasar dalam sehari-harinya seperti merawat kebersihan diri. Meski demikian, peran keluarga dan orang-orang disekitar juga dibutuhkan karena dengan adanya dukungan Subjek dapat meningkatkan kemampuannya dalam perawatan diri (Arsova et al., 2014).

Kelebihan dari penggunaan metode token ekonomi ini adalah metode token mudah diberikan kepada pasien psikotik dimana mereka hanya membutuhkan sedikit pemahaman untuk melakukan target perilaku. Subjek dapat melakukan kegiatan sederhana dan mendapatkan penguatan berupa token serta pujian untuk memotivasinya agar tetap dapat merawat diri dari kebersihan. Pemberian penguatan dapat meningkatkan perilaku merawat diri pada Subjek. Ia menjadi lebih termotivasi untuk membersihkan diri. Akan tetapi, penguatan yang diberikan perlu dilakukan penjadwalan yang jelas sebelum dilakukannya intervensi agar target perilaku yang ingin dicapai dapat terlaksana dengan penjadwalan yang terstruktur (Aprilianti et al., 2017).

Selain itu, pemberian rewards juga perlu diperhatikan dan disesuaikan dengan sesuatu yang disukai oleh Subjek agar menjadi lebih termotivasi. Akan tetapi, pemberian rewards ini merupakan motivasi ekstrinsik dimana individu melakukan suatu kegiatan dikarenakan dorongan dari luar (Sunarsih \& Holidy, 2017). Untuk itu, motivasi instrinsik lebih diperlukan agar Subjek dapat mempertahankan perilaku yang dikehendaki tanpa disertai dengan penguatan atau rewards dari orang lain. Motivasi dari dalam diri ini dapat berupa kesadaran diri akan pentingnya menjaga kebersihan dan merawat diri untuk menjaga kesehatan. Subjek menunjukkan adanya perubahan perilaku dalam merawat diri karena ia menyadari pentingnya merawat diri dalam kehidupan sehari-hari dan termotivasi untuk menjaga kebersihan diri. Subjek juga memiliki perawat yang selalu memantau perilaku perawatan dirinya. Dengan demikian, Subjek dapat terus mempertahankan perilakunya. Keterbatasan dari intervensi ini adalah klien mampu menerapkan target perilaku dengan mudah. Hal ini terjadi karena target perilaku yang ditentukan dalam intervensi merupakan aktivitas yang sehari-hari dapat dilakukan oleh klien. Oleh karena itu, klien dapat dengan mudah mencapai target perilaku perawatan diri.

\section{Simpulan}

Berdasarkan hasil intervensi ini dapat disimpulkan bahwa aktivitas merawat diri dengan token ekonomi cukup efektif untuk memotivasi agar tetap menjaga kebersihan dirinya. Subjek dapat membiasakan diri untuk merawat diri dan menyadari tentang pentingnya merawat diri dalam kehidupan sehari-hari.

Berdasarkan kesimpulan tersebut, penerapan token ekonomi sebaiknya lebih terprogam dan terstruktur agar pelaksanaannya dapat memberikan pengaruh yang lebih efektif dan perilaku yang diharapkan dapat meningkat secara signifikan. Selain itu, perlunya dukungan dari keluarga dan orang-orang disekitar akan semakin mempercepat peningkatan kemampuan perawatan diri. Dukungan yang dapat diberikan keluarga adalah terus memberikan motivasi dan pengawasan agar perilaku yang telah terbentuk dapat menetap dan Subjek mampu secara mandiri melakukan perawatan diri.

\section{Referensi}

American Psychological Association. (2013). Diagnostic and statistical manual mental disorder 5th ed. Washington, DC. British Library

Aprilianti, Heryanto, D., \& Mulyasari, E. (2017). Penerapan teknik modifikasi perilaku token ekonomi untuk meningkatkan kedisiplinan siswa kelas $\mathrm{V}$ sekolah dasar. 
Jurnal Pendidikan Guru Sekolah Dasar. 2(4), 63-75https: //doi.org/10.17509/jpgsd.v2i4.14007

Arsova, S., Bajraktarov, S., Barbov, I., \& Hadzihamza, K. (2014). Patients with schizophrenia and self-care. Journal of Medical Sciences. 2(2), 289-292 https://doi.org/10.3889/ oamjms.2014.048 t

Bai, Y., Yang, X., Zeng, S., \& Yang, H. (2018). A case report of schizoaffective disorder with ritualistic behaviors and catatonic stupor: Successful treatment by risperidone and modified electroconvulsive therapy. BMC Psychiatry. 18(67), 1-5 http://doi:10.1186/s12888-018-1655-5

DeRosse, P., Burdick, K.E., Lencz, T., Siris, S.G., \& Malhotra, A.K. (2013). Empirical support for dsm-iv schizoaffective disorder: Clinical and cognitive validators from a large patient sample. PLOS ONE. 8 (5), 1-8 https://doi.org/10. 1371/journal.pone.0063734

Hsu, Y.C., Lin, W.Q., \& Kuo, H. W. (2017). Schizophrenic patients' poor perception in personal hygiene. Mental Health in Family Medicine. 13, 369-374 http://10.25149/1756-8358. 1301006
Joshi, K., Lin, J., Lingohr-Smith, M., Fu, D.J., \& Muser, E. (2016). Treatment patterns and antipsychotic medication adherence among commercially insured patients with schizoaffective disorder in the united states. Journal Clinical Psychopharmacol. 36, 429-435 10.1097/JCP. 0000000000000549

Rus-Calafell, M., Gutierrez-Maldonado, J., Ribas-Sabate, J., \& Lemos-Giraldez, S. (2014). Social skills training for people with schizophrenia: What do we train? Behavioral Psychology. 22(3), 461-477 http://CorpusID:38282553

Sasmita, H., Mahdairta, R., \& Asterina. (2012). Pengaruh metode token economy terhadap aktivitas perawatan diri pada pasien defisit perawatan diri. Ners Jurnal Keperawatan. 8(1), 23-30 https://doi.org/10.25077/njk.8.1.24-31.2012

Sunarsih, Manurung, I., \& Holidy. (2017). Pengaruh terapi token terhadap kemampuan mengontrol perilaku kekerasan pada pasien gangguan jiwa. Jurnal Keperawatan. 8(2), 234-238 http://dx.doi.org/10.26630/jkep.v13i2.937

Tas, S., \& Buldukoglu, K. (2018). Early period self-care ability and care requirements of schizophrenia patents after discharge. Journal of Psychiatric Nursing. 8(9), 11-22 http: //10.14744/PHD.2017.64935 